Дана стаття створена в рамках реалізації проекту «Стратегічні комунікаиії як інструмент реалізації національних інтересів: украӥнський та закордонний досвід" за кошти Державного бюджету (Наказ МОН від 4.12.2020).

Iva Pavlenko

Zaporizhzhia National University

\title{
The Genesis of Socio-Philosophical Understanding of the Peace and War Relationship in the Social World Development
}

The article is devoted to research the genesis of the relationship between peace and war in the development of the social world was determined. It was found that the social world in concrete historical manifestations was considered by philosophers through the functioning of state-building processes of government and self-organization, and the absolutization of one of them led to war, and harmonization - to peace. The stages of formation of the problem were traced and the traditions of understanding the social world were determined. The first stage was characterized by the study of the world as a cosmic phenomenon - in the natural philosophical, mythological and cosmogonic traditions - and social - in the socio-organic, polis, paternalistic-subject traditions. The second stage - the dominance of the theocentric position - was characterized by the distinction between Heaven and Earth. The third stage - modernism was marked by the dominance of the objectified world in connection with the invention of printing, the development of the institute of education, institutionalization of science. The fourth - stage of industrial institutionalization and world institutions, which was characterized by the consideration of peace and war as a world phenomenon, marked by ideological, idealistic, materialistic, managerial, psychological and peacekeeping traditions. In the fifth - the stage of information and virtual worlds formation, which took place in the integrity of the relationship "society - technology", it was highlighted the system-holistic tradition. The sixth is the modern stage of the synergetic world, defined by the phenomena of hybrid and network war and peace and connected with the hybrid, network and synergetic traditions. Here the problem of the world as a whole in the dynamic uncertainty and technological aspect of the subjects' activity is actualized.

Keywords: social life, peace, war, life actor, social world, genesis

\section{Іва Павленко}

Запорізький національний університет

\section{Генеза соціально-філософського розуміння відносин миру та війни у розвитку соціального світу}

Стаття присвячена дослідженню генезису взаємозв'язку миру та війни у розвитку соціального світу. Було встановлено, що соціальний світ у конкретних історичних проявах розглядався філософами через функціонування державотворчих процесів управління та самоорганізації, і абсолютизація одного 3 них призвела до війни, а гармонізація - до миру. Простежено етапи формування проблеми та визначено традиції розуміння соціального світу. Перший етап характеризувався дослідженням світу як космічного явища - у натурфілософських, міфологічних та космогонічних традиціях - та соціального - у соціальноорганічних, полісних, патерналістсько-предметних традиціях. Другий етап - домінування теоцентричної позиції - характеризувався різницею між Небом і Землею. Третій етап - модернізм - ознаменувався пануванням об'єктивованого світу у зв'язку з винаходом друкарської машини, розвитком інституту освіти, інституціоналізацією науки. Четвертий - етап промислової інституціоналізації та світових інституцій, який характеризувався розглядом миру та війни як світового явища, що відзначався ідеологічними, ідеалістичними, матеріалістичними, управлінськими, психологічними та миротворчими традиціями. П'ятий етап - етап домінування інформації та створення віртуальних світів, що проходив у цілісності відносин «суспільство - технологія», в якій виділено системно-цілісну традицію. Шостий - сучасний етап синергетичного світу - визначається явищами гібридної та мережевої війни та миру, які пов'язані з гібридними, мережевими та синергетичними традиціями. Тут актуалізується проблема світу в цілому в динамічній невизначеності та технологічному аспекті діяльності суб'єктів.

Ключові слова: соціальне життя, мир, війна, суб'єкт життя, соиіальний світ, генеза 


\section{Research topicality}

7 o study the peace and war relationship in the social world development, it is necessary to determine the genesis of understanding this phenomenon, its essence in specific historical manifestations. Therefore, to explain the semantic space of the topic, we traced the stages of the issue formation, clarified the historical and philosophical understanding of the main aspects of this issue. The two main problems in the study of the topic are, firstly, the peace and war relationship in the world's development and, secondly, the consideration of the social world. In modern philosophy, the concept of "social world" is considered conventionally, in cases where it is necessary to determine the existence of social relations between people, the absence of war, peace, social environment. It reproduces only the absolutization of war or peace in the social world understanding, but it is necessary to explore the relationship of opposite processes in the phenomenon development.

The state of scientific development. A comprehensive approach to the war and peace study is presented in the works of C. Clausewitz, in particular in his conceptualization of integral war notion; E. Wide, R. Cowin, L. White studied the features of military and peacemaking activity; H. Tierney explicated the world's development in opposite processes of chaos and order; V. Sagatovsky studied the world as an integral system; A. Pershitsa, Y. Semenov, V. Schnirelman analyzed the functions of war; I. Panarin studied the complex nature of information warfare, etc.

The research purpose is to analyze the genesis of socio-philosophical understanding of the relationship between peace and war in the social world development.

\section{Main material}

At the first stage of the study, we note that the social world understanding and the peace and war relationship, was not the subject of independent analysis in the ancient world. They were considered in the context of a more general problem - the search for an ideal model of the state that guarantees harmony and order on the earth. The origins of this problem are connected, first of all, with the holistic image of the world, which in particular in India was anthropomorphic. The first stage dates from about VIII - II centuries BC in the period of "axial time" according to K. Jaspers, who was characterized by imagery of thinking (Ясперс, 1991, p. 35). I. Nadolnyi drew attention to the fact that K. Jaspers devoted a special study to the worldviews' psychology (Надольний, 1999, p. 7). Therefore, the central issue of philosophical understanding of this period was the structure of the universe, understanding of the human world, the cosmological theme. The world was perceived by images as a cosmic phenomenon, dominated by natural philosophical, mythological and cosmogonic traditions, the ontological aspect in the study of being.

Indian philosophy of the time was characterized by a close connection with religious traditions that penetrated deeply into all spheres of public consciousness. The world was considered from a spiritual point of view and there was a clear distinction between the Divine and Earthly worlds (Антология мировой философии, 1969, p. 11). In the Upanishads, society was seen as a social organism, the image of Purusha, or the spiritual beginning of existence, reproduced the image of the absolute and the first principle of the world. This tradition can be called socio-organic.

In accordance with the socio-organic approach, the social structure of ancient India was formed, which consisted of four varnas. Varna defined the social hierarchy in society (Hepy, 1989, p. 129). This division of society was a strict tradition that defined sustainable socio-economic forms in Indian society. This social structure became inert and rigid to the development of society, but had great potential for the society's survival. For example, all the conquerors of India became a new caste of Kshatriya varna, and therefore there were no upheavals of the social structure. This demonstrates a stable self-organizing basis of society. Also, there was a dislike of the militant intentions of neighboring states, each member of society had "his place" in it and did not change it, following the so-called principle of "Jajman". Consequently, devotion to one's 
country and to what one possesses has played a huge role in life. Thus, the social world in ancient India was perceived as the peaceful coexistence of citizens not only within its system (cities, settlements, etc.), but also in relation to other neighboring peoples.

In the VIII-VI centuries BC began the transition from religious and mythological ideas to a rationalist view of the world in general and the state in particular. In ancient China, he was one of the first to consider the question of building a social world as a place of relations between the state and society of Lao Tzu. In Tao de Jin, the thinker remarked that "the best ruler is the one about whom the people know only that he exists. Somewhat worse are those rulers whom the people love and glorify. Even worse are those rulers whom the people fear, and worst of all are the rulers whom the people despise" (Древнекитайская философия : собрание текстов, 1972, p. 119). The philosopher warned that the government, with the help of religious postulates, forces people to actions and lifestyles that are hostile to the natural course of events in society. Spontaneity in self-organization and minimization of control and management by the state is the basis for a successful society and prevent warfare in the country.

He was opposed by Confucius, according to whom the main condition of human life in the world is compliance with the laws and rules of the state. The essence of the social order is expressed by the formula: "The ruler should always be the ruler, the servant - the servant, the father - the father, the son the son" (Древнекитайская философия : собрание текстов, 1972, p. 148). That is, for Confucius, the main meaning in the social world is order, social hierarchy, observance of laws, norms, which will later contribute to the formation of a natural respect for peace and harmony in society and contribute to the absence of warfare. Confucius laid the foundations of public administration in Chinese civilization, and the order and punishment for its violation positioned as the basis for a peaceful social world.

There were three religious concepts in ancient China: Confucianism, Taoism and Chan Buddhism (Абаев, 1983, pp. 21, 46, 72). A kind of anarchism, chaotic processes in the organization, typical of the Taoists, were harshly criticized by the Confucians. Representatives of Taoism, in turn, criticized the rationalism and uncompromisingness of Confucianism. That is, there was an absolutization of one side: either management or self-organization, which destabilized peace in the social world and provoked military processes. The position of Chan Buddhism was to free people from strict rules and norms and thus develop discipline and cultural behavior in society.

In ancient China, we distinguish the paternalistic-citizen tradition in the issue, its time limits correspond to V - III centuries BC. The principle of paternalism is the embodiment of the practice of public administration, based on the paradigm of education and control of the father over the children in the patriarchal family (Патернализм). Thus, paternalism in ancient China became a mean of protecting the existing order from the threat of destruction by war, and the ruler was given the role of father to the people as a guarantor of peace and the absence of war.

In ancient Greece, the object of study was not only the phenomena of nature, but also the world of man himself, his relationships with others and his individual existence. Prominent ideas in the philosophy of society and government were put forward by Plato and Aristotle, and the understanding of the world was reflected in the world of the polis and the ecumenism. The polis tradition of comprehending the problems touched upon by this research (VI - III centuries BC) was started.

Plato introduced the doctrine of ideas, the so-called "eidos", and asserted the existence of two worlds: the world of ideas (eidos) and the world of things or forms. Ideas give rise to the reality of the world and are the primary source of all material, but matter itself cannot create anything (Платон, Пир, 2007). The philosopher reflected the concept of idea in human consciousness as a formative model of being, and also depicted the things of the real world, their relationship to each other and to man. That is, the thinker first formulates the idea of stratification of the social world.

The absolute opposite of the world of 
ideas is absolutely passive matter, non-being, something immeasurable, meaningless, something that cannot be understood, correctly expressed and reproduced (Платон, Теэтет, 2007, p. 364). Thus, the concept of the world of non-existence appears as the opposite of reality, the eternal struggle of truth and untruth, good and evil. Thus, Plato formulates dialectical ideas.

In addition to the world of ideas and the world of things, there is a sensory world, somewhat intermediate and middle in relation to the previous two areas. It is in him that the "soul of the world", or world soul, is located. "The soul is similar to the divine, and the body is similar to the mortal" (Платон, Федон, 2007, p. 46). That is, between the body and the soul is the unity and confrontation of good and evil, life and death, divine and perishable.

Regarding public administration, Plato believed that the most important thing - to understand how to run the state, this skill is called prudence and justice (Платон, Пир, 2007, p. 143). “... That always and everywhere profits be accompanied by justice, prudence, honesty, or some other part of virtue. If this is not the case, then it will not be a virtue, even when the good is achieved" (Платон, Менон, 2007, p. 389).

In the work "Menon" describes that in the world of ideas themselves there is a single goal, part of the highest goal of all that exists - the idea of good, good. The concepts of "justice", "prudence", "honesty" illustrate the axiological aspect of the world and society. Good is identified with peace, and the opposite state of world justice is embodied in war.

Aristotle considered the construction of an ideal state to be his most important task. He believed that all the activities of the emperor and the legislator are aimed at creating a policy, and the state system is the organization of its citizens (Аристотель, 1983 , p. 444). That is, the polis is a selfgoverning structure with socio-political and economic principles, hierarchical relations between rich and poor. Thus, the policies regulated the state of the social world, in accordance with the idea of harmony and order asserted the absence of war and the achievement of peace.
Polises had political, legal and other institutions - a system of democratic selfgovernment with the right and duty of every full citizen, member of the policy, to participate in public affairs (Васильев, 1998, p. 88). The central square of the polis, the Agora, was jointly owned by all citizens of the polis. The most severe punishment was the expulsion of a citizen from this area, i.e. neglect of his freedom, property, personality, expulsion from the community - ostracism. In the management of the policy, the emphasis was on the system of private-law guarantees with the protection of the interests of every citizen. A citizen of the polis, a person who achieves change for the better by his own efforts, is equal to other citizens, is bound by them in bonds of solidarity and obeys laws passed democratically on a self-organizing basis. And this means achieving peace in the social world.

A. Uyomov in his work analyzed the study of Aristotle on the existence of two worlds: earthly and heavenly (Уемов, 1970, стр. 27). These are the first mentions of the interconnection of elements in the system, as well as the complexity of the functioning, self-organization and organization of independent parts of the world, the relationship of two opposite but inseparable worlds.

The social world in ancient Greece was seen as an existing social order, philosophers identified the threat of its destruction and developed means and mechanisms to protect the social order from war. Thus, in the ancient world we distinguish the following traditions of understanding the social world: social-organic, paternalistic-citizen, polis, in which the world was defined as a social phenomenon.

Thus, the first stage was characterized by the study of the world as a cosmic phenomenon - in the natural-philosophical, mythological and cosmogonic traditions, and social - in the socio-organic, polis, paternalistic-citizen traditions.

Religious worldview was formed during the Middle Ages. This is the next stage of the study of the issue, during which the world, society and the state were considered with the dominance of the theocentric position.

Thus, Blessed Augustine distinguished 
from the real world the Divine, the otherworldly. This is the first dialectical combination of inner and outer worlds. The philosopher believed that the world owed its existence to God. "... Since the world means the first work of a spiritual being, it would be necessary for there to be a corporeal, i.e. our visible world, which was created in (subsequent) two days from these two largest substances that make up the universe..." (Августин Блаженный, 2000, p. 475). Тhe relationship between peace and war was embodied in the internal contradictions of the sacred world of man, who had access to the outside world. The more harmonious the inner world of each individual, the more peaceful the outer world is.

Thomas Aquinas focused on the proof of God as the "first engine" of all things and argued this way: "therefore, it is necessary to come to something primarily driving, which is not set in motion, and everyone understands God" (Фома Аквинский, 2002, p. 380). The lack of ontological meaning further emphasizes the significance of God as a majestic being and does not require reflection on his existence or non-existence. The epistemological aspect of these reflections is the belief that the world was created by God.

In "On Being and Essence", Thomas Aquinas continued the idea of God's selfcreation and the impossibility of endowing a thing with being on its own. That is, God was given the role not only of creating the world, but also of all processes of peace and war, harmony and discord among people.

Thus, the second stage is characterized by the dominance of the theocentric position in the study of the world, religious worldview and the distinction between the world and the heavenly and earthly world. Of particular importance was the concept of St. Augustine with the distinction of temporal modalities. At this stage we distinguish the theological tradition of understanding the social world.

The third stage - modern, was characterized by the humanist movement and the rejection of the theological justification of social life and the world. This has led to radical changes in all areas of ideology and worldview. Time frame of the period - XIVXVIII centuries.
N. Machiavelli identified the world with the state, which he compared with other components of society, and the idea of public administration was proclaimed an art. "If a conquered state has lived freely since time immemorial and has its own laws, there are three ways to keep it. The first is to destroy; the second - to move there to live; third - to give citizens the right to live by their laws, while imposing their tax and entrusting the government to a small number of people who would vouch for the friendliness of the emperor" (Макиавелли, 2003, p. 73). The philosopher portrayed the structure of the state as a special world with its own laws and regulations. N. Machiavelli tried to prove the need for a strong and powerful army and troops. There was a desire for freedom and the destruction of the then order, which was characterized by a deep political, social and economic crisis. Consequently, the state was given a major role in maintaining peace in the social world.

T. More held opposing views on the role of the state and government. He professed a utopian, proto-socialist concept of world order, which means that society determined the basic processes of peace and war, governance and self-organization in the social world. "It is incompatible with the royal dignity to exercise their power over the poor, but rather over people who are sufficient and wealthy" (Mop, 1978, p. 234). Thus, the axiological aspect is manifested in the respect of human freedom, equality between people, the creation of well-being in society on a reliable humane basis.

T. Campanella also considered the main cause of all misfortune - the stratification of society, the existence of wealth and poverty, i.e. social inequality. The only way out is to live in a community, when "the community makes everyone rich and poor at the same time: rich because they have everything, poor because they have no property; and therefore, they do not serve things, but things serve them" (Кампанелла, 1978, p. 97).

The scientist also showed solidarity with T. More on military affairs. He paid great attention to military exercises and a welltrained army, but not in order to fight, but in order for society to feel unity not only in prosperity and peace, but also in social 
protection. Thus, according to the works of T. More and T. Campanella, the ideas of utopian socialism depicted society and the state as an attempt to form a fantastic world in the definition of order. The ideal structure of the world was transposed into the real world, that is, there was an absolutization of the ideal.

R. Descartes saw the world as independent of God. "Changes in the world cannot be directly attributed to God's actions, because his actions are perfectly unchanged. Therefore, I attribute them to nature. The rules by which these changes are carried out, I call the laws of nature" (Декарт, 1989, p. 200 ). Thus, the creation of the world belongs to the Lord, but the chaotic processes that arise in it are inherent only in nature. Thus, R. Descartes had a dialectical worldview in the development and independence of emerging processes. He reflected the reconciliation of the worlds: religious and scientific, thus creating a dualistic conception of the world. Cartesius saw the world as a substance, an attribution in which peace is manifested in the process of reconciliation.

F. Bacon also did not consider God the only source of all things. He imagined the world in the image of the Lord, that is, the totality of all things, the universe. "It is extremely correct to depict the body of nature, which has a dual shape, because the bodies of the higher sphere are different from the bodies of the lower" (Бэкон, 1971, p. 193). The thinker depicted the duality of the world organism, which is characterized by different in nature processes of order, for the higher sphere - people, and chaos - for the lower sphere, i.e. the world of nature. The Lord's metaphor embodied processes similar to management in opposition to chaos.

The philosopher defended the idea of humanism and was opposed to tyranny. "There must always be a just, pious, respectable and sympathetic cause of war. Among all the causes of the war, the desire to overthrow the tyranny, under the oppression of which the exhausted and exhausted people suffer" (Бэкон, 1971, p. 201). That is, if the established order in the world is destroyed by military action, such a process is possible only for the noble cause that unites the whole society for the liberation of the people, and not for the usurpation of power or the introduction of tyranny. Thus, the world began to be seen as an interaction and dialectical combination of opposite processes of peace and war. And the task for society was to find the right way to organize the system.

T. Hobbes paid great attention to the issues of world governance as building order and harmonious interaction of society with the state. "It is necessary to have control over people, but not total and militant, but to prevent military conflicts and correct the manifestations of leadership in society, which stem from the differences between mental and physical" (Гоббс, 1991, p. 110). Thus, in human nature, T. Hobbes found three main causes of war: first rivalry; secondly - distrust; third, the thirst for glory. With good governance, society regulates its needs and ambitions to prevent the destruction of the state and the world at large. Thus, in understanding the problem of the social world, the philosopher considered the processes of management and selforganization of society to prevent war and maintain peace.

B. Spinoza believed that freedom and necessity are compatible: "That supreme power is the best in which people live in harmony, and when their rights are exercised inviolably" (Спиноза, 1957, p. 300). Therefore, a person who is formed in freedom and respect on the part of the state, the main meaning of life will be peace and the absence of war in the world.

J. Locke considered the ideal state of society in the voluntary association of citizens, the so-called social contract, which was concluded between the people and the state. "We have a clear difference between the state of nature and the state of war; and these states, no matter what some people claim, are as far apart as the state of peace, good will, mutual assistance, security and the state of enmity, anger, violence and mutual destruction" (Локк, 1988, p. 272). Therefore, the main goal of the state is to protect the natural rights of people, the rights to life, freedom and property.

J. J. Rousseau saw the social world as the absence of slavery and the rule of law, freedom. Society needs freedom and will, 
but, at the same time, people need to regulate their own lives, and therefore the supreme ruler, who would establish common rules to achieve a common goal (Pycco, 1998, p. 86). J. J. Rousseau insisted that only one principle - the public will can help to achieve the common good and peace, only such a will can control the forces of the state and the people. Equality of all citizens and a common sense of unity and desire for peace create the necessary conditions in the social world to prevent war.

In "Critique of Pure Reason" I. Kant explored the difference between the Cognizable and the Divine world. Using a holistic approach, he defined the world as a whole (Кант, 1994, pp. 350-370). Thus, the ontological aspect is manifested in the existence of essentially different worlds: living and non-living, sensory and cognitive.

Another important line of Kant's philosophy is the concept of thing-in-itself or essence, and things-for-us or phenomena and things for others (Кант, Критика чистого разума, 1994, pp. 400-420). Hence the notion of the transcendence of the world. The transcendent world as a field outside the individual is not known, and the inner world that exists in each individual is known.

As for the structure of the social world, I. Kant expressed a clear position on the peaceful and military situation in the state. Every country has the right to war, but only if there is danger - then it is necessary to accumulate military forces. He insisted that war and peace have nothing in common, they are completely opposite concepts. I. Kant even distinguished the concept of "truce" from "peace", because "no peace treaty should be considered as such, if its conclusion secretly preserves the basis of a new war" (Кант, К вечному миру. Спор факультетов. Антропология. Успехи метафизики, 1994, p. 380). Thus, the philosopher saw war and peace as completely opposite but interacting states, from which the social world is built, its structure.

I. Kant had a negative attitude to the standing armies in the states: "Permanent armies (miles perpetuus) must eventually disappear completely" (Кант, К вечному миру. Спор факультетов. Антропология. Успехи метафизики, 1994, p. 13). A state of peace between people is not a natural state, so people live in constant threat of war, and constant armies motivate society to go to war and wait for the necessary time to start a war.

For Hegel, the whole world, all things are represented in the form of levels of sequential development of the absolute idea: "... It is the own activity of the logical idea determines itself to the future and develops into nature and spirit" (Гегель, 1970, p. 260). The philosopher explored the main question - what is this absolute idea that gives rise to the whole world? An idea that contains the totality and unity of the whole Universe, that is, the being of being.

"Being, indefinitely directly, is in fact nothing and no more, and no less than nothing" (Гегель, 1970, p. 20). He compares being with a blank slate, the beginning of existence, because the history of being arose from nothing, from emptiness. The philosopher distinguishes between "definite, finite" being, "pure being and pure nothingness" and "existing being" (Гегель, 1970, pp. 25-27).

A. Schopenhauer in his work "The world as a will and imagination" considers the world as a subjective idea of each individual (Шопенгауэр, 1999, p. 21). The epistemological aspect is the finding of man as an individual in the world, i.e. his knowledge, which is the determining carrier of the whole world as an idea. Man is the main element of the world, he knows and studies the world in his subjective nature.

The philosopher revealed in his work such concepts as "reality" and "actuality": Realität and Wirklichkeit (Шопенгауэр, 1999 , p. 23). Society, the matter of the world has the ability to influence reality and thus distort and change the space around it. This is a completely natural change within the boundaries of reality.

Hence, we can draw an analogy with the social world, the main feature of which A. Schopenhauer considered "agreement, in which there are all parties and parts of the world" (Шопенгауэр, 1999, p. 86). The axiological aspect of his theory is manifested in the assertion of the value of consent and consent of all members of society. Not only in the inner world of man, which depends on the will and is determined by virtues, but 
also in the outer. Thus, A. Schopenhauer considered the world in all its aspects, namely the relationship of each individual to the world. Man's will was seen by him as the driving force, power and thirst for life in the world, and vice versa, he understood any force in nature as will, because the concept of "power" is fundamental in the knowledge of the objective world.

J. Fichte believed that the real purpose of the human race is not intelligent existence, but intelligent formation through freedom. The last highest goal of society is full consent and unanimity with all its possible members (Буржуазная философия конца XIX века, 1971, p. 239). That is, peace is seen in the sense of harmony in society.

A. Bychko and I. Bychko specify that J. Fichte, emphasizing the idea of the primacy of practical (moral and ethical) reason before the "pure" mind, puts in the center of his philosophical attention the free activity of the human self. All reality in J. Fichte is active, and everything active is a reality. Activity is a positive absolute reality (Бичко, Бичко, \& Табачковський, 2001, p. 132).

Thus, in the XIX century, philosophers began to work actively on the definitions of the inner and outer, sensory and natural worlds. The theme of transcendental reality acquires central importance in their works. In classical German philosophy, the idea of world and being took a leading position.

G. Skovoroda also developed the idea of the duality of the world on the inner and outer, as well as the infinity, the eternity of matter, which he identified with God. "... The infinite end, the beginning without the beginning and God is all one" (Сковорода, 1973 , p. 332). We see the ontological aspect in the existence of God as the creator of all beings and the cause of life of all living things.

S. Krymskyi, researching the work of G. Skovoroda, notes that the philosopher considers the acts of creation of the world, set out in the Book of Genesis as symbols of self-creation of the inner world of man (Кримський, 2002, p. 44).

According to another classification of the world, the philosopher distinguished three worlds: the first is the general and inhabited world, where everything that was born lives.
The other two are partial and small worlds. The first microcosm, or light, saint, or man. The second world is symbolic, or the Bible (Сковорода Г. , 1973). Thus G. Skovoroda recognizes such worlds as the Great World (macrocosm) and Man (microcosm). The Bible appears as a mediator between these worlds, it is a world of words and symbols. These two worlds are in a state of harmonious interaction.

Thus, the third stage is modern, marked by the dominance of the objectified world with the invention of the printing press by J. Gutenberg and the development of the institute of education, institutionalization of science, and the establishment of the world of knowledge. The world was considered not only in the cosmological, theological sense, but in a combination of different processes of peace and war, the importance of the state and public administration over society for harmony in the world, and the differentiation and division of worlds into internal and external, earthly and divine, etc. Thus, we should highlight the progressive tradition in understanding the social world.

From the author's point of view, the next, fourth, stage begins in the middle and end of the XIX century, when the social world underwent qualitative changes, began the rapid development of industry and technology, material relations in society, which led to new philosophical currents and views on human existence.

Ukrainian society at that time experienced problems of peace and war in the everyday world. That is why the Cyril and Methodius Brotherhood embodied the ideas of equality, independence and freedom on the basis of the Christian doctrine of justice, brotherhood and humanity. All members of the Cyril and Methodius Society defended the rights of the people to freedom, liberation, and demanded the abolition of all class privileges and "the abolition of slavery and any humiliation of the lower classes, national inequality, the spread of universal education, the introduction of universal suffrage, and the election of officials" (Костомаров, 1991, p. 11).

In European society, the main tasks of the new Marxist ideological doctrine were also the liberation of the working class 
(proletariat) from exploitation and the construction of a society free from social oppression. "The bourgeoisie, wherever it has achieved domination, has destroyed all feudal, patriarchal, idyllic relations. It turned a person's personal dignity into an exchange value and put in place of countless gifted and benevolent freedoms one unscrupulous freedom of trade" (Маркс, 1959, p. 427). In the work "Manifesto of the Communist Party" the authors clearly describe all the absurdity of the capitalist regime and the bourgeoisie as such. Thus, the axiological aspect of Marx's approach is manifested in the defense of "personal dignity" and the rejection of "unscrupulous freedom of trade". The praxeological aspect is expressed in the comprehension of the actions of the bourgeoisie, which destroyed both the negative influence of feudalism on society and all the moral virtues that were replaced by exchange value and trade relations. Thus, the world in Marxism was seen as a world historical process, and with the development of social relations, conflicts and revolutions began to emerge as special forms of the social world.

The philosophical understanding of this period is determined by the philosophy of life of F. Nietzsche and A. Bergson, who criticized the position of the representatives of socialism as the main current of the stage. F. Nietzsche completely denied the ideas of socialism, in particular regarding the equalization of needs and living standards. "Socialism - as a fully thought-out tyranny of insignificant and unreasonable, i.e. superficial, envious, three-quarters of the actors - is really the final conclusion of the" modern ideas "and their hidden anarchism..." (Ницше, 2005, p. 91). The reason for the creation of socialism as a concept, according to Nietzsche, is the public sense of danger from the elected higher people. But at the same time, the philosopher himself unwittingly contributed to the justification of tyranny, anarchism, absolutizing self-organizing processes. The philosopher saw the paradox of socialism in the fact that each person is not an individual, he is only a slave, an atavism of society. That is, the uprising of the people, excessive selforganization without decent governance in the social world led to warfare. The reason for creating a social world is the public sense of danger and the desire to protect peace from war. Thus, it is necessary to distinguish the ideological tradition in the study of the social world.

A. Bergson in his work "Two sources of morality and religion" describes a closed and open society (Бергсон, 1994, p. 288). In the section "Mechanics and Mysticism" the philosopher describes the main antithesis of an open society - the instinct of war, which is inherent in a closed one. "Wars - the inevitable consequence of the existence of closed societies, as well as nationalism and xenophobia" [18, p. 300]. The ontological aspect of war as the cause of its occurrence is the existence of a closed society. Such a society is hostile to everything around it and does not have a proper level of freedom.

E.Husserl, according to phenomenological ideas about the world, defines it as a set of entities (Гуссерль, 2009, p. 30). All reality is considered within the meanings and meanings that it has and that are used for cognition.

The philosopher distinguished between the existing, practical, natural, material and real worlds (Гуссерль, 2009, pp. 89$93,119,144)$. In his philosophy there is a metaphysical classification of worlds, at the center of which is a fragmentary approach to research. Within each world there are opposite and interconnected processes of chaos and order, peace and war, organization and self-organization, and the set of worlds forms a single integrity of the social world. A holistic approach is used in the development of the types of worlds and their interconnections and interdependencies, and thus the classification becomes a dialectical unity. Thus, in the study we distinguish two more traditions: idealistic and materialistic.

Historical events of the twentieth century. cardinally influenced the further development of understanding of the social world as a contradiction of peace and war, life and death. The first such powerful qualitative changes in the world were the destruction of key empires: Russia and Austria-Hungary, the First World War. Large manufacturing enterprises, factories, and corporations began to form. A. Fayol and F. Taylor 
founded the classical school of management, which emerged during the development of the industrial phase. "To manage means to anticipate, organize, dispose of, coordinate and control" (Файоль, 1923). These were the basic management principles for A. Fayol, which determined the source of efficiency of the system of production processes.

"For each individual, the highest material well-being can occur only when this individual reaches the highest degree of productivity available to him, that is, when he will give the maximum daily output in his work" (Тейлор, 1991, p. 10). F. Taylor saw the community as a tool for profit, and the management of this community was mainly reflected in monitoring the performance of the corporation. Thus, the hallmarks of the period were the increase in profits, the emergence of world capital, man was seen as a tool to achieve high standards of welfare for the upper class, which gave rise to selforganizing confrontation of the masses and the first revolutions within society for dignity and freedom of every citizen. The social world has undergone qualitative changes and a new alignment of priorities in public life. The study of the world was dominated by a functional approach and management tradition.

M. Heidegger noted that for human existence the world is a sphere of practical activity and encouragement of their needs. The question of being in general is very broad and needs definitions in temporal and spatial senses (Хайдеггер, 1999, p. 53). That is, the world that people create around themselves is each individual's own unique world. The author agrees with L. Binswanger, in that $\mathrm{M}$. Heidegger made an attempt to create a new ontology based on the postulate that man is essentially being-in-the-world (Бинсвангер, 1999, p. 14).

When it comes to the social world, there are associations of a peaceful situation in society or finding people side by side with each other. "Peace" is an ontological concept and implies the structure of the constitutive moment of being-in-the-world (Хайдеггер, 1999 , p. 64). The ontological aspect in this definition lies in the essence of the world as being and the Universe of being. Moreover, the world can be called both geographical regions and the sphere of science or art. Thus, Heidegger's phenomenology was focused on the knowledge of human existence, not just its awareness, but also the understanding of being in general. "Peace" acts as a structure of "being" in the world.

A characteristic event of this stage was the Revolution of 1917 in Russia and the emergence of a socialist political system. "The situation when the people are governed should be replaced by self-government of the people" (Маркс, Изменения и дополнения во втором издании брошюры И. Моста "Капитал и труд", 1968, p. 80). Developing the ideas of Marxism, Lenin and the Bolshevik Party proposed the implementation of a socialist revolution, which, in their opinion, would unite the solution of all accumulated problems in society, as well as initiate national liberation and anti-colonial movements.

"Pure democracy" is a liberal phrase that deceives the workers. History knows bourgeois democracy, which replaces feudalism, and proletarian democracy, which replaces bourgeois (Ленин, 1969, p. 251). The country began to create a socialist model of government, which later divided the world into socialist, capitalist and third world countries.

V. Lutai noted that, unfortunately, Lenin's fundamental ideas of democratic centralism for some reason were not only not implemented, but on the contrary, the role of the centralized principle continued to increase, which led to Stalinist and postStalinist totalitarianism in the party and society as a whole (Лутай, 2008, p. 31).

V. Skvorets, studying the way of life of the Ukrainian people in Soviet times, considers a significant shortcoming of the restriction of human freedom in various spheres of public life and approves the process of reproduction of industrial relations (Скворець, 2010, pp. 133-140). Thus, we observe positive moments in the structure of the social world - it is the all-encompassing enthusiasm for building a new society, the implementation of innovations, etc., and negative - the absolutization of governance in society, which led to the destruction of peace in the social world and dissatisfaction.

During this period, O. Bogdanov created 
his work "Tectology", which means general organizational science. "World War is nothing more than an organizational crisis on a global scale, caused by the social spontaneity of mankind, the anarchy of relations between state organizations" (Богданов, 1989, стр. 56). Self-organizational processes were comprehended in the idea of anarchy, the scientist noticed and substantiated the relationship between management and selforganization using a metaphysical approach. During the war, the situation in the social world is unstable, so to study the states and processes in the world it is necessary to stimulate tectological thinking in society.

M. Berdyaev asserted that the Russian revolution is anti-national in nature (Бердяев). The philosopher accused the revolutionary processes of failing to unite society in a natural way, because it happened only for material gain. Russia, according to $\mathrm{M}$. Berdyaev, has changed irreversibly, and emerging ideological conflicts lead to the stratification of society, new misunderstandings and difficulties in managing the disorganized crowd.

I. Ilyin, studying the social processes of that time, was a supporter of democracy and explored two options for governing the state: the state-corporation as a manifestation of the formal democracy of society and the state-institution as a manifestation of the totalitarian regime. The philosopher warns that absolute corporation can lead to anarchy, and the completed principle of organization neutralizes people's initiative, extinguishes freedom of spirit and leads to violence (Ильин, 1993).

Thus, O. Bogdanov, M. Berdyaev and I. Ilyin foresaw the severe consequences of unreasonable public administration in the social world and felt in the absolutization of this process the uneven development of society and the main cause of warfare. This once again confirms the development of philosophically sound ideas of management and self-organization of the philosophy of the twentieth century as drivers of peace or war in the social world.

Freud's psychological concept defined the instinct of life "Eros" and the instinct of death "Thanatos", as well as necrophilia as the opposite of biophilia. "All living things die due to internal causes, return to the inorganic, so we can say: the purpose of all life is death, and, conversely - the inanimate was before the living" (Фрейд, 2001, p. 46). That is, the emergence of World War II and the thirst of individuals to destroy the living and any system, the scientist saw in natural instinct. The opposite position of S. Freud states "the existence of a thirst for self-preservation, which we attribute to every living being” (Фрейд, 2001, p. 48). Along with the desire for destruction, living organisms try to protect themselves from death, and the preservation of existence and the thirst for life are as strong as the thirst for death. This is the paradox of human existence, which reveals the cause of destructive processes in the social world.

K. Horney also studied the psychological aspects of peace and war. "The search for love and affection is one of the ways often used in our culture to soothe anxiety. The search for power, prestige and possession is the second such way" (Хорни, 1993, p. 127). Thus, power, prestige and possession are identified with the need for love, and the lack of positive emotions, happiness a person compensates in domination over someone or something. The desire for power, prestige and possession leads to war and the destruction of the world system. Thus, the author considers it necessary to highlight the psychological tradition in the study of sociophilosophical understanding of the work.

Gradually, the world began to acquire the qualities of the world economic and political system with a set of changing and stable qualities, processes. The Second World War of 1939-1945 initiated the formation of a new democratic system of world order, and the leading geopolitical and geoeconomic positions changed. The methods of achieving peace during hostilities were strict management and strategic thinking, which had an impact on the further development of social relations and the mechanism of peacemaking in the social world.

One of the results of military events was the study of an open system of government in the cybernetic approach of N. Wiener as one of the types of social management (Винер, 1983).

Also during the Second World War, the 
theory of operations was widely used to plan hostilities. The following theory, proposed by P. Hershey, was called situational management. There is a theory of strategic management (J. Barney, B. Wernerfelt, R. Whittington). That is, the cybernetic approach to management, theories of situational, strategic management were used not only to achieve economic growth in the postwar world, but also transposed to the management of society to prevent chaotic and anarchic manifestations in the social world.

From the end of the 1940 s, accelerated developments began, which, as they grew, began to change the borders, structure, and dynamics of economic growth. In 1946, Churchill's Fulton speech signaled the beginning of the Cold War between the capitalist and socialist systems, and also stimulated anti-communist ideas and the policies of humanism in the world. The creation of international organizations, such as the United Nations, UNESCO, the World Bank, the Club of Rome, etc., which advocate the absence of war, conflict, and peace, have become mechanisms to counter the emergence of a new world war. For example, the activities of the Club of Rome, represented by J. Forrester, D. Meadows, M. Mesarovich, E. Pestel, A. Peccei, etc., are aimed at studying the global problems of today, understanding the difficulties of human development and changing public opinion on these challenges (Club of Rome, n.d.). Therefore, the peacekeeping tradition should be singled out in the study of the world.

In general, the world in the postwar period is transformed in accordance with the new world economic, social, political, environmental, military-technical, spiritual and cultural requirements and rules. Thus, in the twentieth century. after World War II, the era of modernization began.

G. Derlugyan, studying the state of the world system and the main processes that occur in the world, noted that the classical revolutions began with a general panicked awareness of the inadequacy of the old regime and its shameful failure in the face of external threats (Дерлугьян, 2013, p. 125). This led to self-organization of the population, the search for management alternatives to achieve progress in all spheres of public life. Such revolutionary sentiments of the people were accompanied by dissatisfaction of various segments of the population, because among society there are both supporters of the old regime and those who seek change. Revolutionary conflict is defined as the source of the subjects of war and peace, governance and self-organization. Therefore, it is necessary to study the processes in the social world only taking into account the world historical context.

Thus, the fourth stage is the stage of industrial institutionalization and world institutions, marked by ideological, idealistic, materialistic, managerial, psychological and peacekeeping traditions. A significant change that determined the position in the worldview was the industrial phase, which led to the consideration of peace and war as a world phenomenon. This phase was characterized by the emergence of world capital, world war, peace as overcoming war. The new trend of existentialism reproduced the understanding of the absurdity of war, as well as the search for the cause of hostilities and ways to resolve conflicts. The world institutions of the United Nations, UNESCO, etc. were formed to comprehend world problems. After the formation of the Club of Rome, the concept of the peaceful existence of the capitalist and socialist worlds emerged.

The consequences of the events described above were the ideological establishment of peace on Earth, the development of the information society, and, accordingly, the formation of information and virtual worlds, there was a discussion of a systematic approach and psychologizing management. These features characterize the next, fifth, stage.

It is important to define a systemic approach for our study. The following positions should be taken into account in its consideration: first, the direction of the methodology of scientific cognition, based on the consideration of the object as a holistic complex of interconnected elements (I. Blauberg, V. Sadovskyi, E. Yudin); secondly, a set of interacting objects at the biological level (L. von Bertalanffy); third, a 
set of entities and relationships (A. Hall, R. Fagin). And since the social world is a whole with a set of different fragments, including peace and war, chaos and order, organization and self-organization, etc., it is appropriate to study the issue with a systematic approach.

Another approach - poststructuralism is the embodiment of the principle of individual freedom, the power of chance, voluntarism, irrationality in human action. Poststructuralist K. Levi-Strauss, poststructuralists J. Derrida, J. Lacan, R. Barth and postmodernists F. Guattari, J. F. Lyotard, M. Foucault and others advocated the idea of creating free conditions for the development of the individual and the impossibility of total control of political power over the spheres of life.

M. Foucault considers the right of discourse as the right to speak, which promotes the development of competence in understanding, provides legalized and direct access to the body of already formulated statements (Фуко, 2004, p. 142). The need for discourse is determined by the harmonious combination of opinions of different individuals. Discourse is designed so that society does not oppose or contradict itself. Through comparison of facts, arguments, historical analysis, the truth can be achieved. That is, in discourse, freedom of action, thought, free access to information, harmony is born in the social world.

After the two World Wars and the attempt of the world community to hinder the war-making processes, the information revolution is gradually brewing, and a new information society, driven by new technologies, is emerging. The author of the concept of information society is $J$. Masuda: information permeates production, management, politics, life and all other aspects of human life (Masuda, 1983, pp. 336-338). The scientist put forward the idea of a new management of society on the basis of participatory democracy, the expediency of which is determined by the global problems of mankind: the relationship of war and peace in the social world, nuclear energy development, environmental pollution, inflation, international terrorism, etc. members of society and coordinated actions of all citizens.
Thus, the fifth stage was characterized by the formation of information and virtual worlds, which are based on objective and objectified worlds, at the center of which is the subjective world of man and the relationship "society - technology". In view of this, we should highlight the systemicholistic tradition in understanding the world.

At the present stage of the synergetic world we observe such trends in the development of the social world as hybrid and network warfare, hence the need to develop similar peacekeeping processes. Contradictions in international relations between states affect the state and form of social relations.

I. Wallerstein studied the modern world according to the world-system approach. "Studying the world system, we come to understand that intellectual activity is determined not only by intellectual or volitional qualities, but also by social timeliness - in the world-system sense" (Валлерстайн, 2004, p. 274). That is, society has the ability to use intellectual opportunities to build a new world on the basis of modern democracy and organization.

According to the network approach of $\mathrm{M}$. Castells, new types of technologies, namely - the Internet define a new world order, the state of the economy, politics, etc., the whole society is forced to exist on the basis of network rules (Кастельс, 2000, pp. 8-15). There is a network business with new features, network social communication, network relationships, network war and peace, which are a distorted network effect (Коновал, 2019; Пічугіна, 2019; Ороховська, 2019).

It is necessary to turn to the worldview approach of P. Kopnin, which traces how the worldview affects the cognitive activity and social ideals of scientists, the search for and justification of the practical consequences of new scientific theories (Копнин, 1974, pp. 5-10). A person's worldview has a great social impact on his further actions and in general on the formation of subjects' respect for peace in the social world.

From the standpoint of a synergetic approach, the world is studied as the unity of order and chaos, war and peace, self-organization and management in the development of the social world as a complex non-equilibrium system. 
Thus, A. Nazaretyan, considering the origins of the harmony of nature and the balance of aggressions that form a flexible self-organizing system of the biosphere, turns to a synergistic generalization of fundamental factors that make inevitable social conflicts and periodic exacerbation of anthropogenic crises, but also serve as development. The first is the exhaustion of resources to support persistently unbalanced processes, which leads to inevitable competition. The second is the paradoxical tendency of persistently nonequilibrium systems to unstable states. The dialectical contradiction is that such systems are essentially focused on achieving and maintaining stability, but the long-term state of such stability creates their internal imbalance (Назаретян, 2012, p. 99).

Thus, we can distinguish the sixth modern stage of the synergetic world, marked by the emergence of hybrid and network war and peace. At this stage there is a problem of holistic, dynamic uncertainty as a factor of subjective design, which are covered in the world-system approach of I. Wallerstein, the network approach of M. Castells, and there is a need to combine different approaches to understand ways to achieve peace in the social world. At this stage, we distinguish between hybrid, network and synergetic traditions in the study of the social world.

\section{Conclusions}

Thus, in this paper the genesis of the relationship between peace and war in the development of the social world was determined.

It was found that the social world in concrete historical manifestations was considered by philosophers through the functioning of state-building processes of government and self-organization, and the absolutization of one of them led to war, and harmonization - to peace. But the dialectic of these dichotomies requires further study in the context of a globalized social world. Therefore, for further research, the stages of formation of the problem were traced and the traditions of understanding the social world were determined. The first stage was characterized by the study of the world as a cosmic phenomenon - in the natural philosophical, mythological and cosmogonic traditions - and social - in the socio-organic, polis, paternalistic-subject traditions (philosophers of ancient India, Lao Tzu, Confucius, Plato, Aristotle). The second stage - the dominance of the theocentric position - was characterized by the distinction between heaven and earth in the philosophy of St. Augustine and Thomas Aquinas. Here the theological tradition developed. The third - the stage of modernism - was marked by the dominance of the objectified world in connection with the invention of printing, the development of the institute of education, institutionalization of science and was associated with the progressive tradition represented by N. Machiavelli, T. More, T. Campanella, R. Descartes, F. Bacon and others. The fourth is the stage of industrial institutionalization and world institutions (UN, UNESCO, etc.), which was characterized by the consideration of peace and war as a world phenomenon, marked by ideological, idealistic, materialistic, managerial, psychological and peacekeeping traditions. K. Marx, F. Engels, F. Nietzsche, A. Bergson, F. Taylor, Z. Freud, N. Wiener, P. Hershey, J. Barney, etc.). In the fifth - the stage of formation of information and virtual worlds, which took place in the integrity of the relationship "society - technology", we highlight the system-holistic tradition. He is represented by I. Blauberg, V. Sadovskyi, E. Yudin, and others. The sixth is the modern stage of the synergetic world, defined by the phenomena of hybrid and network war and peace and connected with the hybrid, network and synergetic traditions. He is represented by I. Wallerstein, G. Hacken, I. Prigozhyn, O. Knyazeva, S. Kapitsa, V. Bekh, V. Andrushchenko, V. Voronkova and others. Here the problem of the world as a whole in the dynamic uncertainty and technological aspect of the subjects' activity is actualized. 


\section{REFERENCES} Nauka.

Abaev, N. V. (1983). Chan'-buddizm i kul'tura psikhicheskoj deyatel'nosti v srednevekovom Kitae. Novosibirsk:

Avgustin Blazhenny`j. (2000). Ob istinnoj religii. In Avgustin Blazhenny`j, Tvoreniya (Vol. 1). Sankt-Peterburg; Kiev: Aletejya; UCzIMM Press.

Antologiya mirovoj filosofii (Vol. 1). (1969). Moskva: My`sl`.

Aristotel`. (1983). Sochineniya (Vol. 4). Moskva: My`sl`

Bergson, A. (1994). Dva istochnika morali i religii. Moskva: Kanon.

Berdyaev, N. A. (n.d.). Dukhi russkoj revolyuczii. Retrieved from E`lektronnaya biblioteka Gramotej: http://www. gramotey.com/books/371140173942.htm

Binsvanger, L. (1999). By`tie v mire : vvedenie v e’kzistenczial’nuyu psikhiatriyu. KSP+ ; Yuventa: Moskva-SanktPeterburg.

Bichko, A. K., Bichko, I’. V., \& Tabachkovs`kij, V. G. (2001). I’stori`ya fi`losofi `yi : pi`druchnik. Kiyiv: Libi`d’.

Bogdanov, A. A. (1989). Tektologiya: vseobshhaya organizaczionnaya nauka. Moskva: E'konomika.

Burzhuaznaya filosofiya koncza KhI'Kh veka. (1971). In Antologiya mirovoj filosofii (Vol. 3). Moskva: My`sl`.

Be`kon, F. (1971). Sochineniya (Vol. 1). Moskva: My`sl`.

Vallerstajn, I. (2004). Konecz znakomogo mira : Socziologiya KhKhI veka. Moskva: Logos.

Vasil’ev, L. S. (1998). Istoriya Vostoka (Vol. 1). Moskva: Vy`sshaya shkola.

Viner, N. (1983). Kibernetika, ili Upravlenie i svyaz`v zhivotnom i mashine. Moskva: Nauka.

Gegel`, G. V. (1970). Nauka logiki (Vol. 1). Moskva: My`sl`.

Gobbs, T. (1991). Sochineniya (Vol. 2). Moskva: My`sl’.

Gusserl', E’. (2009). Obshhee vvedenie v chistuyu fenomenologiyu. In E’. Gusserl', Idei k chistoj fenomenologii i fenomenologicheskoj filosofii (Vol. 1). Moskva: Akademicheskij Proekt.

Dekart, R. (1989). Sochineniya (Vol. 1). Moskva: My`sl`.

Derlug yan, G. (2013). Kak ustroen e`tot mir : nabroski na makrosocziologicheskie temy`. Moskva: Izd-vo In-ta Gajdara.

Drevnekitajskaya filosofiya : sobranie tekstov (Vol. 1). (1972). Moskva: My`sl`.

Il in, I. (1993). Predposy`lki tvorcheskoj demokratii. In I. Il`in, O gryadushhej Rossii : Izbranny`e stat’i. Moskva: Voenizdat.

Kampanella, T. (1978). Gorod Solncza. Moskva ; Leningrad: Izd-vo Akademii nauk SSSR.

Kant, I. (1994). K vechnomu miru. Spor fakul'tetov. Antropologiya. Uspekhi metafiziki. In I. Kant, Sobranie sochinenij (Vol. 7). Moskva: ChORO.

Kant, I. (1994). Kritika chistogo razuma. In I. Kant, Sobranie sochinenij (Vol. 3). Moskva: ChORO.

Kastel`s, M. (2000). Informaczionnaya e`pokha : E`konomika, obshhestvo i kul`tura. Moskva: Gos. un-t Vy`ssh. shk. e'konomiki.

Konoval, V. O. (2019). Merezhevi` tekhnologi`yi u suchasnikh umovakh suspi 'l’nogo rozvitku: fi’losofs'ki konczepczi yi. I’nvesticzi 'yi: praktika ta dosvi d(2). doi:10.32702/2306-6814.2019.2.134

Kopnin, P. V. (1974). Gnoseologicheskie i logicheskie osnovy`nauki. Moskva: My`sl`.

Kostomarov, M. I'. (1991). Zakon Bozhij : (Kniga buttya ukrayins 'kogo narodu). Kiyiv: Libi`d’.

Krims`kij, S. B. (2002). Fenomen mudrosti`u tvorchosti` Grigori ya Skovorodi : do 280-ri'chchya vi’d dnya narodzhennya ukrayins `kogo mislitelya. Vi`snik Naczi`onal’noyi akademi`yi nauk Ukrayini(12), 42-46.

Lenin, V. I. (1969). Iyul' 1918-mart 1919. In V. I. Lenin, Polnoe sobranie sochinenij (Vol. 37). Moskva: Politizdat.

Lokk, D. (1988). Sobranie sochinenij (Vol. 3). Moskva: My`sl’.

Lutaj, V. S. (2008). Suchasni’ fi’losofs'ki’ zasadi reformuvannya ukrayins`koyi sistemi "osvi`ta - nauka virobnicztvo". Fi' losofi ya osvi ti : naukovij chasopis(1-2), 22-34.

Makiavelli, N. (2003). Gosudar’. In N. Makiavelli, Traktaty`. Moskva; Khar`kov: AST; Folio.

Marks, K. (1959). Manifest Kommunisticheskoj partii. In K. Marks, Sobraniya sochinenij (Vol. 4). Moskva: Institut Marksa - E`ngel’sa - Lenina - Stalina pri CzK KPSS ; Gospolitizdat.

Marks, K. (1968). Izmeneniya i dopolneniya vo vtorom izdanii broshyury` I. Mosta "Kapital i trud". Voprosy` istorii $\operatorname{KPSS}(2), 67-80$.

Mor, T. (1978). Utopiya. Moskva: Nauka.

Nadol'nij, I’. F. (Ed.). (1999). Fi`losofi ya : navchal’nij posi` bnik. Kiyiv: Vi`kar.

Nazaretyan, A. P. (2012). Antropologiya nasiliya i kultura samoorganizaczii : ocherki po e'volyuczionnoistoricheskoj psikhologii. Moskva: Knizhny`j dom "LIBROKOM".

Neru, D. (1989). Otkry`tie Indii : v 2 kn. Moskva: Politizdat.

Niczshe, F. V. (2005). Volya k vlasti : opy`t pereoczenki vsekh czennostej. Moskva: Kul`turnaya Revolyucziya.

Orokhovs'ka, L. A. (2019). Transformaczi ya soczi`al no-ekonomi`chnikh vi'dnosin u merezhevomu suspi'l'stvi`.

Problemi sistemnogo pi'dkhodu v ekonomi'czi'. Zbi`rnik naukovikh pracz'(5 (73)). doi:https://doi.org/10.32782/25202200/2019-5-4

Paternalizm. (bez dati). Otrimano z Novaya filosofskaya e`ncziklopediya: http://iph.ras.ru/elib/2279.html

Pi’chugi na, Yu. O. (2019). Nova kul`tura v konczepczi’yi merezhevogo suspi`l’stva Manuelya Kastel`sa. Young Scientist(1 (65)). doi:https://doi.org/10.32839/2304-5809/2019-1-65-4 
Platon. (2007). Menon. In Platon, Sochineniya. Sankt-Peterburg: Izd-vo S.-Peterb. un-ta; Izd-vo Olega Aby`shko. Platon. (2007). Pir. In Platon, Sochineniya (Vol. 2). Sankt-Peterburg: Izd-vo S.-Peterb. un-ta; Izd-vo Olega Aby`shko. Platon. (2007). Tee`tet. In Platon, Sochineniya (Vol. 2). Sankt-Peterburg: Izd-vo S.-Peterb. un-ta; Izd-vo Olega Aby`shko.

Platon. (2007). Fedon. In Platon, Sochineniya. Sankt-Peterburg: Izd-vo S. Peterb. un-ta; Izd-vo Olega Aby`shko.

Russo, Zh.-Zh. (1998). Ob Obshhestvennom dogovore, ili Princzipy` politicheskogo Prava. Moskva: KANONpress; Kuchkovo pole.

Skvorecz', V. O. (2010). Zhittyeustri’j ukrayins`kogo narodu: vi`d radyans`koyi do postradyans koyi epokhi. Gumani`tarnij vi`snik Zapori`z’koyi derzhavnoyi i’nzhenernoyi akademi`yi(40), 133-145. dumka.

Skovoroda, G. (1973). Vi`rshi`. Pi`sni`. Bajki. Di`alogi. Traktati. Pritchi`. Prozovi` perekladi. Listi. Kiyiv: Naukova

Skovoroda, G. (1973). Sochineniya (Vol. 1). Moskva: My`sl`.

Spinoza, B. (1957). Izbranny`e proizvedeniya (Vol. 2). Moskva: Gospolitizdat.

Tejlor, F. U. (1991). Princzipy` nauchnogo menedzhmenta. Moskva: Zhurnal "Kontrolling" ; Izd-vo standartov.

Uemov, A. I. (1970). Analogiya v praktike nauchnogo issledovaniya : iz istorii fiziko-matematicheskikh nauk. Moskva: Nauka.

Fajol`, A. (1923). Obshhee i promy`shlennoe upravlenie. Moskva. Otrimano z http://gtmarket.ru/laboratory/ basis $/ 5783$

Foma Akvinskij. (2002). Voprosy`1-43. In Foma Akvinskij, Summa teologii (Vol. 1). Kiev; Moskva: E’l'ga; Nika Czentr; E'l'kor MK.

Frejd, Z. (2001). Po tu storonu princzipa udovol'stviya. Khar'kov ; Moskva: Folio ; AST. kniga.

Fuko, M. (2004). Arkheologiya znaniya. Sankt-Peterburg: ICz "Gumanitarnaya Akademiya" ; Universitetskaya

Khajdegger, M. (1999). By`tie i vremya. Moskva: Ad Marginem.

Khorni, K. (1993). Nevroticheskaya lichnost` nashego vremeni : Samoanaliz. Moskva: Progress ; Univers.

Shopengaue'r, A. (1999). Mir kak volya i predstavlenie. In A. Shopengaue`r, Sochineniya (Vol. 1). Moskva: TERRA-

Knizhny`j klub; Respublika.

Yaspers, K. (1991). Smy`sl i naznachenie istorii. Moskva: Politizdat.

Club of Rome. (n.d.). Retrieved from Club of Rome: http://www.clubofrome.org

Masuda, Y. (1983). The Information Society as Postindustrial Society. Washington: World Future Society.

\section{Pavlenko Iva}

Ph.D., Assoc. Prof., https://orcid.org/0000-0001-9994-6477, iva.fsu@gmail.com

Стаття надійшла / Article arrived: 19.01.2021

Схвалено до друку / Accepted: 17.02.2021 